BARBARA LITERSKA

UNIWERSYTET ZIELONOGÓRSKI

\title{
OPERA „DER WEISSE ADLER” RAOULA MADERA JAKO PRZYKŁAD TRANSKRYPCJI MUZYKI FRYDERYKA CHOPINA UWIKEANEJ W POLSKĄ TEMATYKĘ NARODOWOWYZWOLEŃCZĄ
}

$M$ uzyka Fryderyka Chopina w wersji operowej jest rzadkością, a zaistniała na pewno w dwóch kompozycjach: Chopin autorstwa Giacoma Oreficego (premiera 25 XI I90I r. w Teatro Lirico w Mediolanie) ${ }^{\mathrm{I}}$ oraz Der weisse Adler Raoula Madera (premiera 22 XII I9I7 r. w wiedeńskiej Volksoper) ${ }^{2}$. Tematem pierwszej, czteroaktowej opery jest życie Chopina ułożone w cztery fabularyzowane obrazy ${ }^{3}$. Druga opera prezentuje barwną biografię Tadeusza Kościuszki ujętą w trzy akty ${ }^{4}$ W obu tych utworach mamy do czynienia z transkrybowaniem dzieł chopinowskich, gdyż ich warstwę muzyczną stanowi wyłącznie muzyka Chopina w różnorodnych opracowaniach5' Ten fakt dowodzi recepcji Chopina na europejskich scenach muzycznych w I poł. XX stulecia.

Przedmiotem niniejszych rozważań jest opera pt. Der weisse Adler ${ }^{6}$ traktowana jako transkrypcja muzyki Chopina. Moim celem jest przybliżenie tego nieznanego

I Zob.: William Ashbrook, „Chopin”, w: New Grove dictionary of opera, red. Stanley Sadie, London I996, t. I, s. 850 .

2 Zob.: Barbara Denscher, Der Operettenlibrettist Victor Léon. Eine Werkbiografie, Bielefeld 2017, s. 483.

3 Akt I - w Żelazowej Woli, Wigilia Bożego Narodzenia I826 r., Chopin przebywa w towarzystwie przyjaciół (Chopin - tenor, Elio - baryton, Stella - sopran). Akt II - w podparyskiej willi Flory (George Sand), wiosna I837 r., Chopin uwodzi Florę (mezzosopran). Akt III - na Majorce I839 r., Chopin i Flora z córką Grazią (rola cicha) i jej tragiczna śmierć podczas burzy. Akt IV - w Paryżu, I849 r., śmierć Chopina, zob.: W. Ashbrook, op. cit.; Jan Stanisław Witkiewicz, „Chopin, czyli rola dla tenora”, Maestro 20Io, s. 4-6, online: http://www.maestro.net.pl/document/kurier/Rok_Chopinowski.pdf, dostęp 30 VI 20I9; Giacomo Orefice Chopin Opera in 4 atti-composta sulle melodie di Frederic Chopin - Versi di Angiolo Orviet [CD], Dux 2010.

4 Akt I - w Wilnie I774 r., młody Kościuszko odrzucony przez rodzinę ukochanej Ludwiki Sosnowskiej. Akty II i III - w Krakowie I794 r., insurekcja kościuszkowska.

5 W operze Chopin są to opracowania nokturnów, mazurków, Berceuse, Barkaroli, Fantazji na tematy polskie op. I3, por.: W. Ashbrook, op. cit.; J.S. Witkiewicz, op. cit.; Grzegorz Wiśniewski, Leksykon postaci operowych, Kraków 2008, s. 38. Der weisse Adler bazuje na ponad trzydziestu różnych kompozycjach, o których jest mowa w dalszym fragmencie tego tekstu.

6 Utwór ten jest też określany jako operetka, zob.: Alexander Rausch, „Mader, Raoul Maria”, w: Oesterreichisches Musiklexikon online, http://www.musiklexikon.ac.at/ml/musik_M/Mader_Raoul.xml, dostęp 30 VI 20I9. Inni autorzy jednoznacznie wskazują na operę, zob.: Marion Linhardt, „Hirschfeld. I. Victor Leon", w: Musik in Geschichte und Gegenwart, Personenteil, t. 9, Kassel-Stuttgart ²003, s. 66. 
świadectwa artystycznej recepcji muzyki Chopina, dzieła, które powstało na początku XX stulecia w kręgu niemieckojęzycznym. Autorami Der weisse Adler są dwaj libreciści, Victor Léon i Heinrich Hermann Regel, oraz dwaj muzycy, Raoul Maria Mader i Blagoje Bersa. Są to postaci kojarzone przede wszystkim ze światem wiedeńskiej opery i operetki schyłku XIX w. ${ }^{7}$, dlatego też nie odnajdziemy o nich choćby wzmianki w monumentalnym dziele Mieczysława Tomaszewskiego ${ }^{8}$ czy też na stronach Narodowego Instytutu Fryderyka Chopina9 ${ }^{9}$ Pozycję tę wymieniają jedynie Józef Chomiński i Teresa Dalila Turło ${ }^{\text {Io }}$. Taki stan rzeczy sprawia, że poniższe omówienie ma charakter unikatowy i wskazuje nowy obiekt do dalszych badań, nie tylko chopinologicznych. Chciałabym podkreślić, że jest to pierwsza, a zarazem wstępna (więc na pewno niewyczerpująca) próba jego charakterystyki.

Niniejszy artykuł składa się z dwóch zasadniczych części, z których pierwsza dotyczy libretta, a druga - muzyki. Analiza treści libretta koncentruje się na polskiej tematyce narodowowyzwoleńczej zapowiadanej przez sam tytuł opery, jak i podjęty w niej wątek insurekcji kościuszkowskiej. Część druga jest szkicem analityczno-muzycznym bazującym na zmodyfikowanej systematyce transkrypcji utworów Chopina autorstwa Macieja Gołąba ${ }^{\mathrm{II}}$. Podstawę rozważań stanowią libretto ${ }^{\mathrm{I2}}$ i wyciąg fortepianowy partytury $^{13}$ (jako źródła podstawowe) oraz oryginały użytych w operze kompozycji Chopina $^{\text {I4 }}$ (jako źródła porównawcze).

\section{LIBRETTO - POLSKA TEMATYKA NARODOWOWYZWOLEŃCZA}

Nazwa Der weisse Adler (pol. biały orzeł) funkcjonowała w XIX w. w kręgach niemieckojęzycznych jako emblemat polskości ${ }^{15}$. Dla Polaków, a szczególnie tych po-

7 Zob.: Bernard Grun, Dzieje operetki, przekł. Maria Kurecka, rozdz. XXIV napisał Lucjan Kydryński, Kraków i974.

8 Mieczysław Tomaszewski, Chopin. Cztowiek, dzieto, rezonans, Poznań I999.

9 Narodowy Instytut Fryderyka Chopina: http://pl.chopin.nifc.pl/institute/, dostęp 5 VII 2019.

IO Józef Chomiński, Teresa Dalila Turło, Katalog dziet Fryderyka Chopina, Kraków I992, s. 492 (indeks autorzy transkrypcji).

II Por.: Maciej Gołąb, Spór o granice poznania dzieła muzycznego, Wrocław 2003, s. 79-97.

I2 Der weisse Adler. Oper in drei Akten von Victor Léon und H. Regel. Musik von Fr. Chopin. Für die Bühne bearbeitet von Raoul Mader. Textbuch, Leipzig-Wien 1917 Doblinger Musikverlag, online: https://polona. $\mathrm{pl} /$ item/der-weisse-adler-oper-in-3-akten-textbuch,ODE4MTcoNjQ/4/\#info:metadata, dostęp $30 \mathrm{VI}$ 2019 .

I3 Der weisse Adler. Oper in drei Akten von Victor Léon und H. Regel, Musik von Fr. Chopin. Für die Bühne bearbeitet von Raoul Mader, opr. na fort. Blagoje Bersa z podłożonym tekstem słownym, Leipzig-Wien I9I7 Doblinger Musikverlag, s. I56, zob. informacje w: http://www.worldcat.org/title/weisse-adler-operin-drei-akten/oclc/22I8227368referer=brief_results, dostęp 30 VI 2019.

I4 Seria Dzieta Wszystkie Fryderyka Chopina pod redakcją Ignacego Jana Paderewskiego, Ludwika Bonarskiego, Józefa Turczyńskiego. (Kraków-Warszawa I949-6I).

I5 W 1. I864-65 w Szwajcarii wychodziła gazeta Der weiße Adler prezentująca sprawy polskie, a jej wydawcą i redaktorem był Władysław Plater (uczestnik powstania listopadowego i działacz emigracyjny). W Dreźnie w XIX w. pod tą nazwą funkcjonowała słynna restauracja, gdzie spotykała się polska emigracja. 
zostających na emigracji, bliski był wizerunek białego orła na czerwonym $\mathrm{tle}^{\mathrm{I}}$. $\mathrm{Na}$ okładce partytury omawianej opery orzeł rozpościera skrzydła nad Krakowem, gdzie rozpoczęła się insurekcja kościuszkowska I794 roku. Zatem zarówno sam tytuł, jak i szata graficzna podpowiada polską narodowowyzwoleńczą tematykę opery (il. I). Znamienna też jest data wydania partytury oraz prapremiery dzieła przypadająca na rok I9I7, w którym hucznie świętowano stulecie śmierci Tadeusza Kościuszki. Jak pisze Piotr Mitzner:

W roku I9I7 na cześć Kościuszki bito medale, zmieniano nazwy ulic i placów, stawiano pomniki, powielano portrety wodza w tysiącach egzemplarzy. Ukazały się setki książek, artykułów, wierszy, poświęconych Kościuszce ${ }^{17}$.

W tych prezentacjach Naczelnik był wyidealizowanym bohaterem ubranym w białą sukmanę i niosącym nadzieję wolności, był polskim bohaterem narodowym $^{\mathrm{I}}$. Nie można także zapominać, że omawiana opera powstawała w czasie intensywnej międzynarodowej działalności Ignacego Jana Paderewskiego na rzecz polskiej niepodległości.

Autorzy libretta, Victor Léon ${ }^{19}$ i Heinrich Hermann Regel ${ }^{20}$, głównym tematem całej opery uczynili wielkie zasługi Kościuszki dla polskich dążeń niepodległościo-

I6 Piastowski orzeł był pierwotnie totemem plemiennym Polan - Lechitów. W XIII w. symbol Orła Białego przyjęli książęta polscy z rodu Piastów, następnie król Władysław Łokietek ustanowił go herbem Królestwa Polskiego, zob.: Stanisław Russocki, Stefan K. Kuczyński, Juliusz Willaume, Godto, barwy i hymn Rzeczypospolitej. Zarys dziejów, Warszawa 1978; Aleksandra Jaworska, Orzet Biaty. Herb państwa polskiego, Warszawa 2003; Alfred Znamierowski, Orzet Biaty. Znak państwa i narodu, Warszawa 2016.

17 Piotr Mitzner, Teatr Tadeusza Kościuszki. Postać Naczelnika w teatrze I803-1994, Warszawa 2002, s. I54.

I8 Mit o Kościuszce był niezwykle żywy w XIX w., co potwierdza spora liczba utworów dramatycznych powstałych z okazji stulecia wybuchu insurekcji kościuszkowskiej (I894) oraz śmierci Naczelnika (I9I7). Rok 1917 był wielką kulminacją tego kultu, ale też początkiem jego dewaluacji (zastąpienia go kultem Piłsudskiego), zob.: P. Mitzner, op. cit., s. 8-9.

I9 Victor Léon, wł. Victor Hirschfeld (I858-1940), autor czternastu librett, które zostały wykorzystane w operetkach z muzyką Maxa Josefa Beera, Lea Falli, Alfreda Grünfelda, Imre Kálmána, Franza Lehára, Roberta Mahlera, Johanna Straussa (syna), Alfreda Zamara. W okresie III Rzeszy nazwisko Léona (żydowskiego artysty) zniknęło z teatralnych broszur, mimo że nadal wykonywano operetki, do których napisał libretta wraz z Leo Steinem, w tym m.in. Wesotą wdówkę F. Lehara (ulubioną operetkę Hitlera) czy Wiedeńska krew J. Straussa. Mimo niearyjskiego pochodzenia pozostał w Wiedniu aż do śmierci, jego grób znajduje się na tamtejszym Cmentarzu Hietzing. W I955 r. jego imieniem nazwano jedną z ulic w wiedeńskiej dzielnicy Hietzing (Viktor Léon Gasse). Więcej informacji w: B. Denscher, op. cit.; Stefan Frey, „Victor Léon”, w: Lexikon verfolgter Musiker und Musikerinnen der NS-Zeit, red. Claudia Maurer Zenck, Peter Petersen, Hamburg 2009, online https://www.lexm.uni-hamburg.de/object/lexm_ lexmperson_ooo03576, dostęp 30 VI 2019; M. Linhardt, op. cit., s. 63-67; B. Grun, op. cit.

20 Heinrich Hermann Regel (I869-1934), autor librett do opery Oscara Straussa pt. Die Prinzessin von Tragant, do baletu Johanna Straussa pt. Aschenbrödel, baletu Josefa Bayera pt. Die Braut von Korea, oraz dzieła choreograficznego pt. Die Jahreszeiten der Liebe: vier altwiener Tanz-Bilder do muzyki Franza Schuberta w aranżacji na fortepian Juliusa Lehnerta, zob. online: http:/www.worldcat.org/ title/jahreszeiten-der-liebe-vier-altwiener-tanz-bilder-von-heinrich-regel-musik-arrangiert-von-juliuslehnert-klavierauszug-zu-zwei-handen/oclc/83898762, dostęp 3 VII 20I9; http://www.worldcat.org/title/ aschenbrodel-ballett-in-drei-akten/oclc/I3828023I, dostęp 3 VII 20I9; http://www.worldcat.org/title/ braut-von-korea-ballett-in-vier-akten-und-neun-bildern/oclc/94I729622, dostęp 3 VII 2 OI9. 


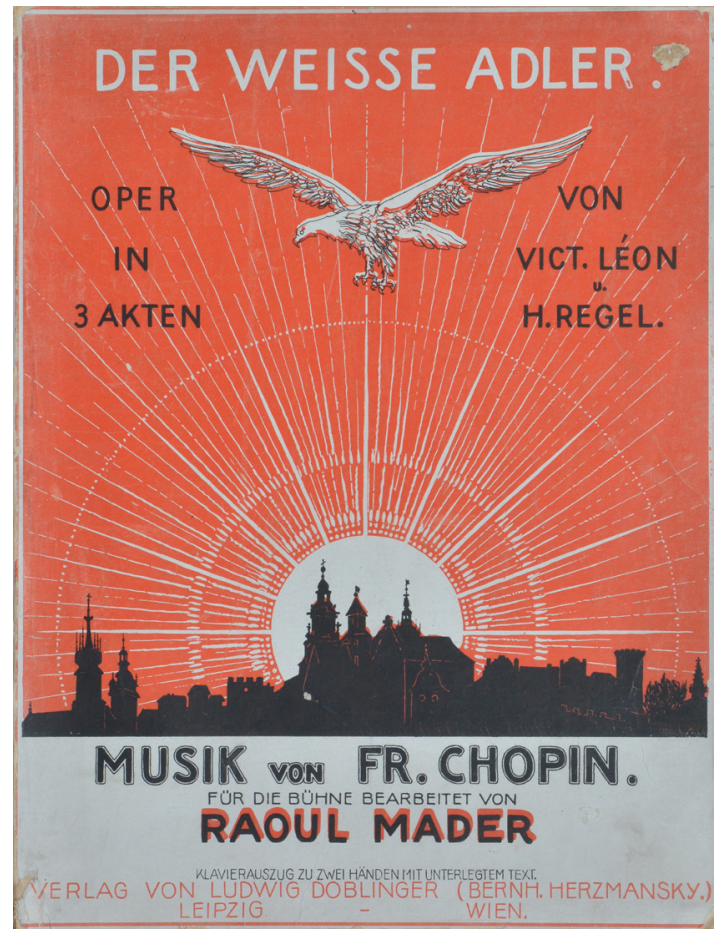

Il. I. Strona tytułowa wyciągu fortepianowego Der weisse Adler. Oper in drei Akten von Victor Léon und H. Regel. Musik von Fr. Chopin. Für die Bühne bearbeitet von Raoul Mader, opr. na fort. Blagoje Bersa z podłożonym tekstem słownym, Leipzig-Wien 1917 Doblinger Musikverlag.

wych, na co wskazuje też jej pierwszy tytuł: Der polnische Reiter ${ }^{2 \mathrm{I}}$. Aby opowieść była ciekawsza, wprowadzili wątek niespełnionej miłości Kościuszki do Ludwiki Sosnowskiej ${ }^{22}$. Ta prawdziwa historia osobista stała się kanwą do opowiedzenia historii o wielkim Polaku, narodowym bohaterze, z którym jego rodacy wiązali wielkie nadzieje, a cały ówczesny świat pamiętał i podziwiał jego działania na rzecz wolności obywatelskiej.

Akcja opery rozgrywa się w drugiej połowie XVIII w. i jest bezpośrednio związana z biografią Kościuszki: fabuła aktu pierwszego rozgrywa się w Wilnie w roku I774, wydarzenia kolejnych dwóch aktów usytuowane zostały w Krakowie dwadzieścia lat później, w 1794 roku. W libretcie mamy do czynienia z fikcją, przedstawione realia zawierają wiele przekłamań w zakresie imion i nazwisk głównych bohaterów, ich wieku czy miejsc, w których rozgrywa się akcja. Co ciekawe, dwie historyczne postacie

2 I Por.: B. Denscher, op. cit., s. $20 \mathrm{I}$.

22 Temat miłosnych perypetii Kościuszki jest frapujący także dla dzisiejszego odbiorcy, zob. Beata Kuźniarowska, „Kościuszkowe Love”, Kurier Historyczny z 2 I 20I8, online: https://kurierhistoryczny.pl/ artykul/kosciuszkowe-love,208, O2 I 20I8, dostęp 3 VII 2019. 
kobiece (Tekla Despot-Zenowicz oraz Ludwika Sosnowska) ukrywające się w sztuce pod innymi imionami i nazwiskami, zostały także odmłodzone. Wydaje się, że z jednej strony był to sposób na odwrócenie od nich uwagi (na zmarginalizowanie ich udziału w obyczajowym skandalu - romansie dobrze urodzonej panny z biednym szlachcicem), a z drugiej strony na uwypuklenie sprawy polskiej, wojskowej, narodowej reprezentowanej przez bohaterów (m.in. Madalińskiego, Ossolińskiego czy Zajączka), którym z kolei lat dodano (zob. tab. I). Głównym zadaniem librecistów było utrwalenie mitu o Kościuszce w wersji przystępnej dla przeciętnego odbiorcy ${ }^{23}$. Moje przypuszczenie potwierdza fakt dziewięciokrotnej prezentacji tego utworu w wiedeńskiej Volksoper, w której dominował lżejszy repertuar w typie śpiewogry, który adresowany był do publiczności szukającej raczej szlachetnej rozrywki, niż prawdy historycznej.

Tab. I. Akt I - fikcja literacka wobec faktów.

\begin{tabular}{|l|l|}
\hline \multicolumn{2}{|c|}{ Postacie w I akcie (I774 r.) } \\
\hline \multicolumn{1}{|c|}{ Fikcja literacka } & \multicolumn{1}{c|}{ Fakty } \\
\hline Tadeusz Kościuszko, kapitan & Tadeusz Kościuszko, kapitan \\
\hline $\begin{array}{l}\text { Andrzej Sosnowski, hrabia, marszałek polny } \\
\text { litewski, według libretta w roku I774 miał 50 lat }\end{array}$ & $\begin{array}{l}\text { Józef Sylwester Sosnowski (I729-83), m.in. } \\
\text { hetman polny litewski (I775-80) w roku I774 } \\
\text { miał 45 lat }\end{array}$ \\
\hline $\begin{array}{l}\text { Cesarine, księżniczka burbońska, żona hrabiego } \\
\text { Andrzeja Sosnowskiego, według libretta w roku } \\
\text { I774 miała 37 lat }\end{array}$ & $\begin{array}{l}\text { Tekla Despot-Zenowicz (ur. ok. I73I r.), żona } \\
\text { J.S. Sosnowskiego'24 w roku I774 miała 43 lata }\end{array}$ \\
\hline $\begin{array}{l}\text { Miette, córka hrabiego Sosnowskiego } \\
\text { i Cesariny, według libretta w roku I774 } \\
\text { miała I8 lat }\end{array}$ & $\begin{array}{l}\text { Ludwika Sosnowska (I75I-I836)25, córka } \\
\text { J.S. Sosnowskiego i T. Despot-Zenowicz, } \\
\text { w roku I774 miała 23 lata }\end{array}$ \\
\hline $\begin{array}{l}\text { Madaliński, pułkownik, według libretta w roku } \\
\text { I774 był po czterdziestce }\end{array}$ & $\begin{array}{l}\text { Antoni Józef Madaliński (I739-I804), polski } \\
\text { generał, dowódca brygady kawalerii z czasów } \\
\text { insurekcji kościuszkowskiej, w roku I774 miał } \\
\text { 35 lat i najprawdopodobniej był w stopniu } \\
\text { pułkownika }\end{array}$ \\
\hline $\begin{array}{l}\text { Ossoliński, wojewoda, } \\
\text { według libretta w roku I774 miał 55 lat }\end{array}$ & $\begin{array}{l}\text { Józef Salezy Ossoliński (I734-90), wojewoda } \\
\text { podlaski (I774-89), w roku I774 miał 40 lat }\end{array}$ \\
\hline $\begin{array}{l}\text { Walerian Lubomirski, książę, sekretarz } \\
\text { gubernatora, według libretta w roku I774 miał } \\
\text { ok. 30 lat }\end{array}$ & $\begin{array}{l}\text { książę Józef Aleksander Lubomirski (I75I-I8I7), } \\
\text { starosta romanowski, kasztelan kijowski, } \\
\text { generał lejtnant, członek konfederacji } \\
\text { targowickiej, w roku I774 miał 23 lata }\end{array}$ \\
\hline
\end{tabular}

23 Więcej na temat recepcji postaci Kościuszki w teatrze zob.: P. Mitzner, op. cit.

24 Por.: Marek Jerzy Minakowski, Genealogia potomków Sejmu Wielkiego, online http://www.sejm-wielki. pl/b/lu.I4326, dostęp 3 VII 2019.

25 Faktycznie Ludwika Sosnowska (po mężu Lubomirska) była ukochaną Tadeusza Kościuszki, którego oświadczyny zostały odrzucone przez jej ojca. Mężem Ludwiki został książę Józef Aleksander Lubomirski. 
W pierwszym akcie występują także postaci fikcyjne: Jehuda ben Levi (Żyd, przyjaciel Kościuszki), jeden służący i dwóch lokajów. Całość rozgrywa się latem w Wilnie, w salonie pałacu Andrzeja Sosnowskiego. I to miejsce jest niezgodne z prawdą historyczną, gdyż w tamtym czasie J.S. Sosnowski mieszkał w okazałym dworze w Sosnowicy (obecnie w woj. lubelskim).

\section{TREŚĆ AKTU I}

Trzej panowie - Sosnowski, Ossoliński, Madaliński - grają w kości przy nieco brudnym stole, na którym stoi szampan, wino, butelka likieru ${ }^{26}$. Wchodzi książę Lubomirski, przynosząc list od Kościuszki dla Sosnowskiego. Po wyjściu Lubomirskiego kompani ustalają, że to ten przystojny i elegancki młodzian będzie zięciem Sosnowskiego, więc już cieszą się na myśl o weselu. Na tę radosną scenę trafiają jego żona i córka: Cesarine i Miette. Panowie wychodzą, a panie szczerze rozmawiają. Córka opowiada matce o pobycie w Wersalu - o przyjaźni z Marią Antoniną, a także o przyjaźni i miłości do Tadeusza Kościuszki ${ }^{27}$. Po chwili wchodzi Lubomirski z bukietem kwiatów, które wręcza Miette i wyznaje jej miłość. Dziewczyna jest zdenerwowana, matka próbuje załagodzić sytuację. Wchodzi Sosnowski, a zaraz po nim Jehuda ben Levi (ubrany w kaftan i bijący niskie pokłony) i zapowiada przybycie Kościuszki. Gdy ten się pojawia, czule wita się z Miette i długo z nią rozmawia. Przygląda się temu matka dziewczyny, podejmuje konwersację, pyta o życie kulturalne w Paryżu. Kościuszko odpowiada, że nie ma wolnego czasu na bywanie w towarzystwie, gdyż wiedzie proste życie - studiuje i służy w wojsku. Matka zauważa, że młodzieniec ma duszę poety i jest bardzo sympatyczny. Wchodzi Sosnowski, wita się po żołniersku z Kościuszką, a ten prosi o rękę Miette. Sosnowski gwałtownie odmawia, obrażając Kościuszkę, wskazując na jego marne pochodzenie i zbyt dużą przepaść społeczną między młodymi. Wzburzony Kościuszko wychodzi ${ }^{28}$.

W dwóch kolejnych aktach opery występują te same postaci oraz kilka nowych (tab. 2). Całość rozgrywa się wiosną 1794 r. w Krakowie na Wawelu. Libreciści nawiązali do sceny rozpoczęcia insurekcji kościuszkowskiej w dniu 24 III I794 r., która faktycznie przebiegała jednak w innym miejscu - na krakowskim rynku.

26 Prawdą jest, że Józef Sylwester Sosnowski wygrał w karty olbrzymie dobra szarogrodzkie w 1768 roku. Majątek ten wniosła w posagu jego córka Ludwika Sosnowska.

27 W rzeczywistości Kościuszko pracował jako nauczyciel Ludwiki na dworze wojewody Józefa Sosnowskiego w Sosnowicy i to wówczas młodzi się pokochali.

28 Kościuszko w tym czasie wrócił z Francji, gdzie oficjalnie pobierał nauki z zakresu sztuk pięknych, a prywatnie z zakresu inżynierii wojskowej w ramach pięcioletniego stypendium ufundowanego przez króla Rzeczypospolitej Obojga Narodów. Po powrocie do Polski, nie mając szansy na pracę w polskiej armii i będąc odrzuconym przez rodzinę ukochanej Ludwiki Sosnowskiej, w roku 1775 wyjechał z kraju przez Drezno i Paryż do Ameryki Północnej. 
Ponadto, w obu aktach występują postacie fikcyjne: Bronia („mleczna siostra” Theidy), Bogumił Dafczenko (narzeczony Broni, chłop pańszczyźniany), Jehuda ben Levi, Janek (majordomus), sługa, Arcybiskup z Krakowa, szlachta, duchowni, żołnierze, żniwiarze, lud, osoby niosące flagi.

Tab. 2. Akt II i III - fikcja literacka wobec faktów.

\begin{tabular}{|c|c|}
\hline \multicolumn{2}{|c|}{ Postacie w II i III akcie (I794 r.) } \\
\hline Fikcja literacka & Fakty \\
\hline $\begin{array}{l}\text { Tadeusz Kościuszko, Naczelny Dowódca } \\
\text { Polskiej Armii }\end{array}$ & $\begin{array}{l}\text { Tadeusz Kościuszko, Naczelny Dowódca } \\
\text { Polskiej Armii }\end{array}$ \\
\hline Andrzej Sosnowski, hrabia, marszałek & $\begin{array}{l}\text { w roku I794 Józef Sylwester Sosnowski nie żył } \\
\text { już od jedenastu lat }\end{array}$ \\
\hline $\begin{array}{l}\text { Theida, księżna Lubomirska, wnuczka hrabiego } \\
\text { Andrzeja Sosnowskiego. } \\
\text { według libretta w roku I794 miała I7 lat } \\
\text { zestawienie tej postaci z A. Sosnowskim } \\
\text { w operze nie było możliwe w życiu realnym }\end{array}$ & $\begin{array}{l}\text { Józef Aleksander i Ludwika Lubomirscy mieli } \\
\text { troje dzieci: Fryderyka, Henryka i Helenę } \\
\text { (I783-I876) } \\
\text { Helena w I794 r. miała zaledwie jedenaście lat, } \\
\text { urodziła się w roku śmierci jej dziadka } \\
\text { J.S. Sosnowskiego }\end{array}$ \\
\hline Madaliński, generał & $\begin{array}{l}\text { Antoni Madaliński - polski generał, dowódca } \\
\text { brygady kawalerii z czasów insurekcji } \\
\text { kościuszkowskiej }\end{array}$ \\
\hline Ossolinński & $\begin{array}{l}\text { Józef Salezy Ossoliński (I734-90), wojewoda } \\
\text { podlaski (I774-89) }\end{array}$ \\
\hline Zajączek, adiutant Kościuszki & $\begin{array}{l}\text { Józef Zajączek (I752-I826), książę, polski } \\
\text { i francuski generał, polityk, uczestnik insurekcji } \\
\text { kościuszkowskiej }\end{array}$ \\
\hline
\end{tabular}

TREŚĆ AKTU II

Sala królewska w Zamku na Wawelu, wejście przez taras do parku. Młodzi polscy szlachcice oraz żołnierze przechadzają się z czerwonymi flagami z białym orłem. Adiutant Zajączek nawołuje młodzież do służby pod dowództwem Kościuszki:

Chodźcie, aby towarzyszyć Kościuszce!

Bohaterowi, który walczy o wolność Polski.

Zwycięzcę powinny powitać polskie flagi!29.

Szlachta odpowiada chórem:

Biały orle leć z dumą przed nami!

Tam, gdzie zataczasz swoje kręgi, pozdrawia nas droga zwycięzcy!

29 „Nun kommt, Kościuszko zu geleiten! / Den Helden, der für Polens Freiheit kämpft. / Den Sieger, sollen Polens Fahnen grüßen!", cyt. za: Der weisse Adler [...] Textbuch, op. cit., s. 38. Cytaty z libretta w przekł. Katarzyny Kwiecień-Długosz. 
Tam, gdzie łopoczesz skrzydłami, wita nas Polska, nasz ojczysty świat!

Biały orle w czerwonym polu, ulecz nas!

Pod twymi skrzydłami zawsze przechadza się bohater!

Leć dumnie przed nami po zwycięskiej drodze! ${ }^{3 \circ}$.

Wszyscy oczekują przyjazdu Kościuszki. Wchodzą Janek majordomus i Ossoliński, potem stary Sosnowski. Przyjaciele rozmawiają. Okazuje się, że Sosnowski został sam (żona i córka już nie żyją) i mieszka na Wawelu wraz ze swoją wnuczką Theidą ${ }^{3 \mathrm{I}}$. Sosnowski boi się spotkania z Kościuszką, którego tak źle potraktował dwadzieścia lat temu. Ma wyrzuty sumienia. Za to jego wnuczka Theida i jej przybrana siostra Bronia bardzo oczekują spotkania z wielkim bohaterem. W końcu nadjeżdża Kościuszko przy dźwiękach głośnej muzyki. Wita go Sosnowski, wywiązuje się między nimi nieprzyjemna rozmowa, Kościuszko nie chce zostać w domu Sosnowskiego (nie przyjmuje chleba i soli z jego rąk). Po długich rozmowach panowie dochodzą jednak do ugody, dzięki wnuczce Sosnowskiego - Theidzie (niezwykle podobnej do swej matki, wielkiej miłości Kościuszki). Wchodzi stary towarzysz Levi, który po miłej, przyjacielskiej konwersacji śpiewa na cześć wodza pieśń autorstwa młodego Dafczenki:

Kościuszko, wielki Polaku,

Bóg ciebie posłał, abyś uwolnił naród i ziemię, którą uciska obcy!

Kościuszko, zbawco Polski,

Jak obraz z brązu pozostaniesz na zawsze w szlachetnym sercu Polski! ${ }^{32}$.

Dafczenko upomina się o pannę młodą, ukochaną, którą chce poprowadzić do ołtarza, oraz o wolność, którą uzyskuje od Kościuszki. Rozpoczyna się bal, przychodzą wszyscy, również wnuczka Sosnowskiego. Kościuszko jest pod urokiem Theidy (jej imię jest żeńskim odpowiednikiem imienia Tadeusz). Sosnowski wręcza Kościuszce list od ukochanej Miette z wyznaniem wiecznej i jedynej miłości ${ }^{33}$.

\section{TREŚĆ AKTU III}

Dnia następnego. Pod Wawelem stoją: lud, szlachta, żołnierze, duchowni, żniwiarze, poczty sztandarowe. Zawołania rozpoczęte przez arcybiskupa są powtarzane przez lud i pełnego zapału Kościuszkę:

30 „Weißer Adler, Flieg' uns stolz voran! / Wo du deine Kreise ziehest, Grüßt des Sieges Bahn! / Wo du flatterst, grüßt uns Polen, Unser Heimatland! / Weißer Adler, In dem roten Feld - Heil uns! / Unter deinem Fittich wandelt Stets ein Held! / Flieg' uns stolz voran, Auf des Sieges Bahn!", cyt. za: ibid.

3I Jest to historia fikcyjna, gdyż w roku I794 J.S. Sosnowski nie żył już od jedenastu lat, a jego córka Ludwika Lubomirska (z domu Sosnowska) żyła i miała wówczas 43 lata. Nieznana jest natomiast data śmierci jego żony, Tekli Despot-Zenowicz, która mogła mieć wówczas 63 lata.

32 „O Kościuszko, großer Pole, / Dich hat Gott geschickt, Daß du Volk und Land befreiest, Das der Fremde drückt! / O Kościuszko, Polens Retter, / Wie ein Bild aus Erz Wirst du ew'ge Zeiten stehen, In der edlen Polen Herz!", cyt. za: ibid., s. 57.

33 Jest to oczywiście historia fikcyjna, gdyż Ludwika Lubomirska (z domu Sosnowska) przeżyła Tadeusza Kościuszkę o dziewiętnaście lat. Prawdą jest, że kochankowie darzyli się głębokim uczuciem przez całe swoje życie. 
Polsko! Zaufaj swoim synom!

Oni walczą dla ciebie!

Oni giną dla ciebie!

Oni zwyciężają! ${ }^{34}$.

Trwa zabawa, do której zaprasza Sosnowski. Tańczą młode dziewczęta, dzieci i kobiety z kwiatami we włosach. Wszyscy są szczęśliwi: Bronia i Dafczenko zostają połączeni przez Kościuszkę. Theida szczęśliwa przy jego boku, wyznaje mu miłość. Ten jednak odtrąca jej uczucie i wyznaje, że kocha w niej wizerunek jej matki (Miette). Theida jest zrozpaczona. Słychać werbel i sygnał trąbki - Kościuszko woła gromkim głosem:

Nadszedł czas, aby uwolnić Polskę! Żegnajcie!35.

Wszyscy odpowiadają:

Wybawienia, zwycięstwa i radosnego powrotu! ${ }^{36}$.

Naczelnik odjeżdża przy akompaniamencie radosnego śpiewu zebranych: „Biały orle”, a smutna, bo zawiedziona w swym młodzieńczym uczuciu Theida, szepce na koniec:

Na zawsze zachowam cię w uścisku i w miłosnym pocałunku ${ }^{37}$.

Der weisse Adler wpisuje się niewątpliwie w krąg tematyczny „Opera wobec historii" ${ }^{38}$. Wpisuje się zarazem w tradycje operowe będące dziedzictwem epoki romantyzmu, dla której tematyka historyczna była bardzo istotna, co niejednokrotnie stanowiło manifestację tendencji narodowych. Jak pisze Ryszard Daniel Golianek:

Sięganie po własną przeszłość narodową, aktualizowanie losów bohaterów z dawnych czasów i tworzenie swoistych mitologii narodowych [...] zaowocowało w dziedzinie opery szeregiem znaczących kompozycji i zadecydowało o traktowaniu gatunku operowego jako jednego z naczelnych mediów identyfikacji narodowej39.

Zastanawia jednak niepolskie pochodzenie jej autorów, którzy w tym przypadku nie odnieśli się do własnej przeszłości narodowej. Choć nie mam na to żadnego dowodu, mogę się domyślać, że dzieło to zostało zamówione przez zamieszkujących w Wiedniu Polaków, którym zależało na uświetnieniu stulecia śmierci Kościuszki i na utrwalaniu w świadomości wiedeńczyków polskich dążeń niepodległościowych, które w niedalekiej przyszłości doczekać się miały przecież realizacji. W tym celu posłużono się trzema czytelnymi wówczas symbolami: postacią Kościuszki, nazwą orła białego i muzyką Chopina scalonymi w jednej operze.

„O Polen! O Polen! Vertrau’ deinen Sohnen! / Sie kampfen für dich! / Sie fallen für dich! / Sie siegen!”, cyt. za: ibid., s. 77.

35 „Nun gilt es, Polen zu befreien! Lebt wohl!”, cyt. za: ibid., s. 89.

36 „Und Heil und Sieg und frohe Wiederkehr!”, cyt. za: ibid.

37 „Ewig werd' ich dich umschließen, und dich küssen”, cyt. za: ibid., s. 90.

38 Opera wobec historii, red. Ryszard Daniel Golianek, Piotr Urbański, Toruń 2012.

39 Ibid., s. 7. 
W Polsce od ponad dwudziestu lat prowadzone są badania nad transkrypcjami muzyki Chopina jako dokumentami jej recepcji. Prace te zapoczątkował Maciej Gołąb, a kontynuatorami byli i nadal są jego uczniowie - Ewa Czernek, Barbara Literska. Ten polski zakres badań odwołuje się do przełomowego dzieła, jakim jest Kata$\log$ dziet Fryderyka Chopina Chomińskiego i Turło ${ }^{40}$. Informacje zawarte w katalogu dały impuls do rozpoczęcia poszukiwań i nadal jest on drogowskazem pomocnym w odnajdowaniu coraz to nowych opracowań Chopinowskiej muzyki. Maciej Gołąb w swojej systematyce transkrypcji ${ }^{41}$ odwoływał się do źródeł dziewiętnastowiecznych, jednak, analizując dokumenty z I poł. XX w., trzeba rozszerzać i korygować zaproponowany przez niego model. Takie wnioski wypływają z prezentowanej poniżej analizy, której celem jest określenie typu i rodzaju transkrypcji, jaką reprezentuje opera Der weisse Adler.

Dzieło Madera zostało opublikowane w Musikverlag Doblinger w I9I7 r. jako wyciąg fortepianowy. Według Petera Pany’ego (obecnego dyrektora wydawnictwa) nie ma dziś śladu partytury orkiestrowej - ani w archiwum wydawnictwa, ani w Bonner Katalog ${ }^{42}$. Z dokumentów wynika jedynie, że w I9I7 r. do orkiestracji opery został zatrudniony kapelmistrz Oskar Stalla, ale nie zachowały się efekty jego pracy. Wersja orkiestrowa musiała jednak istnieć, bo opera była dziewięciokrotnie prezentowana w wiedeńskiej Volksoper począwszy od 22 XII I9I7 roku. Kolejne spektakle miały miejsce w Polsce w 1924 roku. Były też plany jej wystawienia w 1. 1932-34 w ramach festiwalu muzycznego „Opera Górska” w Zakopanem ${ }^{43}$.

Raoul Maria Mader"4 wybrał około trzydzieści kompozycji Fryderyka Chopina i przystosował je do akcji scenicznej. Pisząc niniejsze omówienie, dysponowałam jedy-

Zob. przyp. Io.

4I M. Gołąb, op. cit., s. 79-97. Pierwsze propozycje klasyfikacji transkrypcji zawierają dwie wcześniejsze publikacje: Maciej Gołąb, „Dziewiętnastowieczne transkrypcje muzycznych arcydzieł. Próba typologii na przykładzie utworów Fryderyka Chopina”, Muzyka 45 (2000) nr I, s. 23-45; Barbara Literska, „Dziewiętnastowieczne transkrypcje utworów Chopina. Próba systematyki”, Muzyka 42 (I997) nr 4, s. $37-50$.

42 List z I9 XII 2018 r. od Petera Pany'ego, Dyrektora Musikhaus-Musikverlag Doblinger w Wiedniu, do autorki niniejszego artykułu.

43 W I93I r. dyrygent Juliusz Schreyer zawarł w tym celu stosowną umowę z Musikverlag Doblinger.

44 Raoul Maria Mader (I856-1940), węgierski dyrygent, kompozytor i pedagog. W I879 r. ukończył konserwatorium wiedeńskie, gdzie studiował fortepian u H. Schmitta, organy u Franza Krenna, teorię muzyki u Antona Brucknera. Następnie pracował tam jako nauczyciel fortepianu (1884-95) i chórmistrz Akademische Gesangverein (I890-94). Kilka lat po powrocie do Budapesztu w roku I895 został dyrygentem Węgierskiej Opery Królewskiej (I9OI-I7), a następnie jej dyrektorem (I92I-25), szczególnie dbającym o węgierski repertuar muzyczny. W międzyczasie, w l. I917-I9, był kierownikiem Volksoper w Wiedniu, pracował także jako nauczyciel muzyki. Jest autorem utworów scenicznych: opery komicznej Die Flüchtlinge (I89I), operetek Das Garnisonsmädel (1904) i Der selige Vincenz (1907), baletów Die roten Schuhe (I897) i Wr. Legende (1914), a także utworów chóralnych i pieśni, zob.: B. Grun, op. cit., s. 253, 254, 272; A. Rausch, op. cit. 
nie wyciagiem fortepianowym autorstwa Blagoje Bersy ${ }^{45}$, co ogranicza moje rozważania nad problematyką transkrybowania muzyki Chopina do jej przekładów na fortepian solo z kompozycji w oryginale przeznaczonych na fortepian, fortepian i orkiestrę, śpiew i fortepian. Aranżer wyraźnie zaznaczył, że, wychodząc naprzeciw poziomowi przeciętnego odbiorcy (wykonawcy), starał się zachować równowagę: stosując uproszczenia fakturalne i rytmiczne, zadbał o zachowanie charakteru Chopinowskiej muzyki ${ }^{46}$. Ta deklaracja znajduje potwierdzenie w partyturze, bo w większości przypadków Bersa niemal dosłownie cytuje fragmenty kompozycji Chopina zgodnie z frazowaniem, kadencyjnym zamknięciem zdań muzycznych, bardzo często z zachowaniem tonacji oryginalnej, z niewielkimi uproszczeniami samej muzycznej substancji. Zespolenie tych fragmentów odbywa się za pomocą improwizowanych łączników nawiązujących do motywiki Chopinowskich dzieł.

Partytura liczy I56 stron, są w niej wyodrębnione trzy akty, wskazane są osoby, jednak bez adnotacji dotyczących rodzaju głosów wokalnych, nie ma też informacji na temat orkiestrowej obsady. Ponadto materiał nutowy nie zawiera oddzielnych głosów, nie wiadomo więc, czy partia danej postaci ma być mówiona, czy też śpiewana, gdyż często rytmika tekstu nie odpowiada rytmice melodii wiodącej (zob. przykł. I).

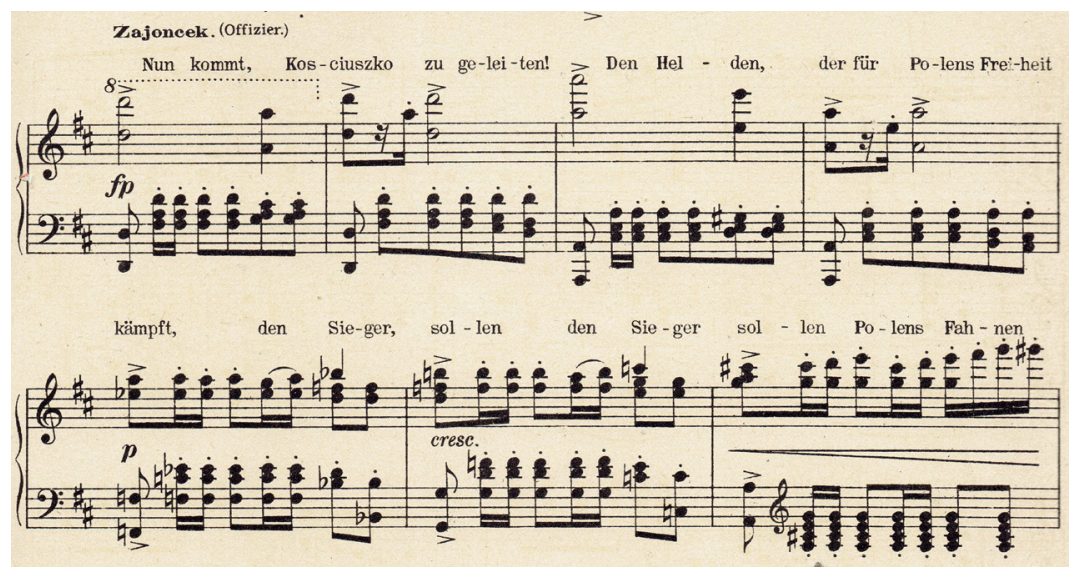

Przykł. I. Opracowanie Poloneza A-dur op. 40 nr I Fryderyka Chopina z aktu II Der weisse Adler. Oper in drei Akten von Victor Léon und H. Regel. Musik von Fr. Chopin. Für die Bühne bearbeitet von Raoul Mader, opr. na fort. Blagoje Bersa z podłożonym tekstem słownym, Leipzig-Wien I917, s. 57.

45 Blagoje Bersa (I873-1934), chorwacki kompozytor, był mistrzem nowoczesnej techniki orkiestrowej. Ma w swoim dorobku kompozycje orkiestrowe, kameralne, fortepianowe, pieśni solowe, chóralne. Jest twórcą opery Oganj (Ogień) prezentowanej w Zagrzebiu w I9II r. oraz opery komicznej Postolar od Delfta (Szewc z Delft) wystawionej tamże w I9I4 roku. Od I9II r. był zatrudniony w wydawnictwie Doblinger w Wiedniu w charakterze konsultanta i aranżera i w ramach tych obowiązków otrzymał zapewne zlecenie przygotowania wyciagu fortepianowego opery Der weisse Adler, zob.: Wacław Panek, „Bersa, Blagoje”, w: Encyklopedia Muzyczna PWM, t. I, $a-b$, Kraków 1979, s. 305-306; Koraljka Kos, „Bersa, Blagoje”, w: Oesterreichisches Musiklexikon online, https://www.musiklexikon.ac.at/ml/musik_B/Bersa_Blagoje.xml, dostęp 30 VI 2019.

46 „Der Bearbeiter des 2 ms. Klavierauszuges Der weiße Adler war bemüht die Schwierigkeiten des Klaviersatzes zu vereinfachen, ohne die Eigenart Chopin's zu beeinträchtigen. Auf diese Weise glaubt er, die Chopin'sche Musik der Allgemeinheit zugänglich gemacht zu haben”, cyt. za: Der weisse Adler [...], opr. na fort., op. cit., s. 2, uwaga od wydawcy. 
Odwołując się do klasyfikacji dziewiętnastowiecznych transkrypcji Chopina ${ }^{47}$, należy stwierdzić, że - spośród pięciu kategorii - cztery są w tej operze reprezentowane, ale proporcje liczbowe między nimi są różne. Transkrypcja substancjalna ${ }^{48}$ jest bardzo rzadko stosowana. Powód wydaje się być oczywisty, w dziele scenicznym nie ma czasu na prezentację całych kompozycji Chopina. Taki zabieg spowodowałby załamanie dramaturgii sztuki. W wyniku analizy partytury odnajdujemy dwa przykłady transkrypcji substancjalnej. Jednym z nich jest opracowanie pieśni Pierścień (Es-dur op. $74 \mathrm{nr} \mathrm{I4}$ ), w którym mamy do czynienia z dosłownym przepisaniem muzyki Chopina na taką samą obsadę jak w oryginale - na fortepian i głos. Mimo braku oddzielnej partii wokalnej, wniosek ten możemy wysnuć na podstawie zgodności rytmiki warstwy muzycznej i tekstowej. Zgodność dotyczy także treści pozamuzycznej, bowiem tekst (tutaj w języku niemieckim) także odwołuje się do wspomnienia zaręczyn i tytułowego pierścienia. Narratorem tych wspomnień w operze jest jedna z młodych bohaterek, Bronia, zakochana w Dafczence - chłopie pańszczyźnianym o duszy poety (zob. przykł. 2).

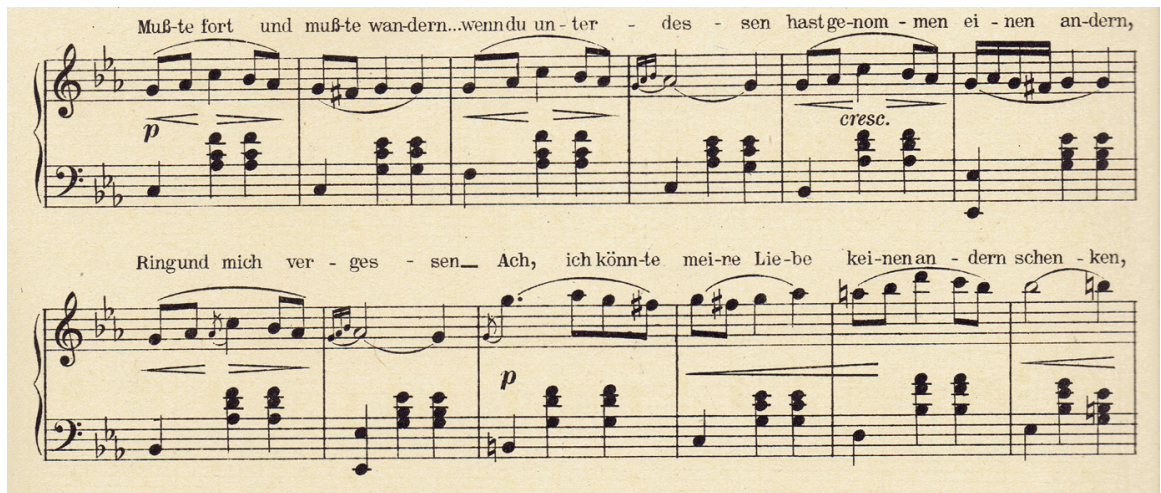

Przykł. 2. Transkrypcja substancjalna: opracowanie pieśni Fryderyka Chopina Pierścień op. 74 nr I4 w akcie II Der weisse Adler [...], opr. na fort., op. cit., s. 77.

47 Maciej Gołąb wyróżnił pięć klas transkrypcji: I) substancjalną (transmitującą warstwy - multiplikującą warstwy), 2) strukturalną (rozbudowującą fakturę - zmieniającą układ warstw fakturalnych), 3) syntaktyczną (redukującą składnię - rozbudowującą składnię), 4) rekontekstową (redukcyjną kontaminacyjną), 5) użytkową (techniczno-dydaktyczną - uproszczona), por.: M. Gołąb, Spór, op. cit, s. 79-97; Barbara Literska, Dziewiętnastowieczne transkrypcje utworów Fryderyka Chopina, Kraków 2004, s. I44.

48 W tym typie transkrypcji praca aranżera polega na ścisłym przepisaniu całej substancji dzieła na nowe medium wykonawcze, co powoduje repartycyjną zmianę faktury. Ta repartycja może polegać wyłącznie na transmisji warstw brzmieniowych (transkrypcja transmitująca warstwy) lub ich zwielokrotnianiu (transkrypcja multyplikująca warstwy). Warunkiem koniecznym pozwalającym na wyróżnienie tego typu transkrypcji jest nienaruszalność substancji muzycznej oryginału, przy czym termin „substancja muzyczna” rozumiany jest jako prymarny kompozycyjnie materiał dźwiękowy (melodyczny, harmoniczny i metrorytmiczny). Takie rozumienie odpowiada jednej tylko „substancji” wg definicji Eggebrechta „prekompozycyjnemu kompleksowi elementów”, zob.: Hans Heinrich Eggebrecht, „Uwagi o metodzie analizy muzycznej”, przekł. Maria Stanilewicz, Res Facta 7 (I973), s. 4I-43. 
Transkrypcja strukturalna ${ }^{49}$, której właściwością jest zachowanie formy i syntaksy dzieła oryginalnego, nie ma swojego reprezentanta z powodu wspomnianego w punkcie pierwszym (opera nie jest chopinowskim recitalem, ale nowym utworem rządzącym się własną dramaturgia). Transkrypcja syn taktyczna ${ }^{50}{ }^{50 ́ w n i e z ̇ ~ z d a r z a ~ s i e ̨ ~}$ nieczęsto i to jedynie w wersji redukującej składnię. Przykładem jest tutaj opracowanie Mazurka D-dur op. 33 nr 3. Chociaż zachowany jest zarys chopinowskiej formy, to w jej ramach skrócone są powtórzenia pewnych zdań muzycznych, jednak przy zachowaniu następstwa treści muzycznych. W konsekwencji oryginalna I36-taktowa forma obejmuje w operze zaledwie 89 taktów. Jest to wersja wyłącznie instrumentalna określona jako „Mazur”, który towarzyszy scenie zabawy ludycznej (przykł. 3).

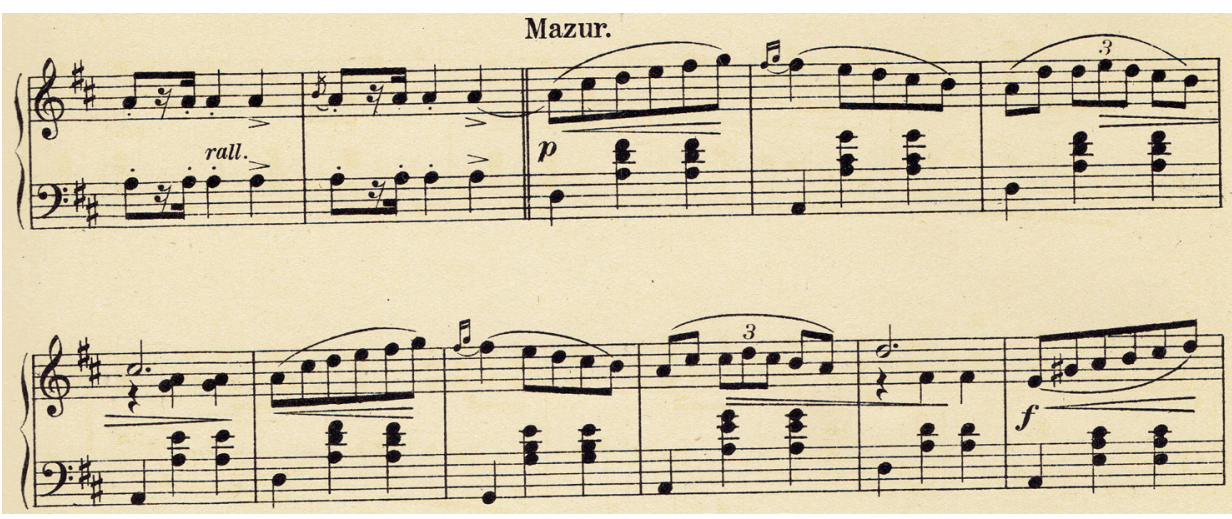

Przykł. 3. Transkrypcja syntaktyczna: opracowanie Mazurka D-dur op. 33 nr 3 Fryderyka Chopina w III akcie Der weisse Adler [...], opr. na fort., op. cit., s. I28 (fragment).

Transkrypcja rekontekstowa ${ }^{\text {sI }} \mathrm{w}$ podtypie redukcyjnym dominuje w całej operze. Polega ona na przywoływaniu wiernych wersji kompozycji Chopina (niemal ich kopii) w formie krótszych, bądź dłuższych incipitów. Przykładem jest fragment Poloneza A-dur op. $40 \mathrm{nr}$ I (t. 25-40 oryginału) towarzyszący scenie oczekiwania licznie zgromadzonej polskiej szlachty na przybycie Tadeusza Kościuszki (por. przykł. I).

49 W typie transkrypcji strukturalnej występuje jakościowa zmiana faktury przy zachowaniu substancji dzieła w zakresie tonalnym, oryginalnej składni oraz formy. Zmiana jakości faktury może polegać na jej rozbudowaniu (transkrypcja rozbudowująca fakturę) lub zmianie układu warstw fakturalnych (transkrypcja zmieniająca układ warstw fakturalnych).

so W transkrypcji syntaktycznej zachowane są jedynie główne kategorie składni, a modyfikacji podlegają jej podrzędne elementy. Wyróżniamy dwa podtypy: transkrypcję redukującą składnię, transkrypcję rozbudowującą składnię.

5I Wyróżnikiem tego typu transkrypcji jest zniszczenie formy dzieła oryginalnego. Następuje ono w wyniku atomizacji fragmentów formy (transkrypcja redukcyjna) lub łączenia fragmentów (lub całych utworów) $\mathrm{z}$ innymi utworami lub ich fragmentami (transkrypcja kontaminacyjna). 
Lista przykładów dla tego typu transkrypcji jest długa i obejmuje dwadzieścia sześć zidentyfikowanych utworów ${ }^{52}$.

Wszystkie cztery omówione powyżej zasadnicze typy transkrypcji (substancjalna, strukturalna, syntaktyczna, rekontekstowa) były rozpoznawane jako fragmenty tego wielkiego dzieła i porównywane do odpowiadających im kompozycji Chopina. Natomiast traktując całą operę jako jedną wielką transkrypcję, możemy zdecydowanie wskazać na typ dyfuzyjny ${ }^{53}$ łączący transkrypcję reko ntekstową kontaminacyjną ${ }^{54}$ z transkrypcją uży tkową ${ }^{55}$ okazjonalną ${ }^{56}$. Ta ostatnia jest nową kategorią wynikającą z zaistnienia ważnej społecznie i politycznie sytuacji związanej z obchodami stulecia śmierci wielkiego bohatera narodowego - Tadeusza Kościuszki.

W ten sposób odmieniona muzyka Chopina stała się nośnikiem polskich treści narodowowyzwoleńczych związanych bezpośrednio z dominującą w operze tematyką insurekcji kościuszkowskiej - polskiego powstania narodowego przeciw Rosji i Prusom z 1794 roku. Elementem muzycznej identyfikacji są emblematy chopinowskie zawsze towarzyszące Tadeuszowi Kościuszce - fragmenty Poloneza A-dur op. 4I nr I (przykł. I) oraz pieśń Wojak op. 74 nr Io (przykł. 4) ${ }^{57}$. Nie mniej istotne są emblematy wizualne wskazujące na dominujące miejsce akcji - Kraków z jego architektonicznymi wyróżnikami - widoczne na karcie tytułowej partytury (por. il. I). Taki charakter opery zdecydowanie wzmacnia wyraźnie rozpoznawalna muzyka Chopina (przedstawiciela Wielkiej Emigracji), symbol Orła Białego (jako tytułu, ale też i głównego bohatera przywoływanego w kilkakrotnie śpiewanym hymnie), postać Kościuszki (symbolu dążeń niepodległościowych i wolnościowych, w tym równości

W kolejności alfabetycznej są to: Etiuda E-dur op. Io nr 3; Fantazja na tematy polskie A-dur op. I3 (temat Karola Kurpińskiego); Impromptu-Fantasie cis-moll op. 66; Koncert e-moll op. II, cz. III Rondo; Koncert f-moll op. 2I; Mazurek C-dur op. 6 nr 5; Mazurek B-dur op. 7 nr I; Mazurek a-moll op. 7 nr 2; Mazurek B-dur op. 17 nr I; Mazurek g-moll op. 24 nr I; Mazurek a-moll (Gaillard) op. posth.; Nokturn Es-dur op. 9 nr 2; Nokturn g-moll op. I5 nr 3; pieśń Wojak op. 74 nr Io; Piosnka litewska op. 74 nr I6; Polonez A-dur op. 40 nr I; Polonez As-dur op. 53; Preludium A-dur op. 28 nr 7; Preludium As-dur op. 28 nr I7; Preludium c-moll op. $28 \mathrm{nr}$ 20; Rondo à la Krakowiak F-dur op. I4 (Introdukcja i Rondo); Scherzo b-moll op. 3I; Walc a-moll op. $34 \mathrm{nr}$ 2; Walc Des-dur op. $64 \mathrm{nr} \mathrm{I}$; Walc h-moll op. $69 \mathrm{nr} 2$; Wariacje B-dur op. I2, temat.

53 Więcej na temat transkrypcji dyfuzyjnej w: B. Literska, Dziewiętnastowieczne transkrypcje, op. cit., s. 2I7-22I.

54 Por. definicję z przyp. 5 I.

55 Według Gołąba podstawową cechą tego typu transkrypcji są rażące zmiany w jednym bądź kilku elementach dzieła i są to zmiany degradujące to dzieło w sensie estetycznym. Do tej grupy należą dwa podtypy opracowań powstałych z powodów pragmatycznych: dydaktycznych (transkrypcja techniczno-dydaktyczna) lub popularyzatorskich na najniższym poziomie artystycznym (transkrypcja uproszczona).

56 Jest to nowy, trzeci podtyp transkrypcji użytkowej wynikający z zaistnienia ważnej (społecznie, kulturalnie lub/i politycznie) okoliczności, zob.: Barbara Literska, „Suita d-moll Milija Bałakiriewa jako przykład recepcji Chopina w Rosji”, Rocznik Chopinowski 26 (2018), s. 59-94.

57 Warto przypomnieć, że ojciec Chopina, Mikołaj, był uczestnikiem insurekcji kościuszkowskiej. Z uwagi na słabą kondycję fizyczną swojego syna, zachęcał go do wyjazdu za granicę tuż przed wybuchem powstania listopadowego, twierdząc, że słaby byłby z niego „wojak”. A sam tekst Stefana Witwickiego do pieśni Wojak Chopina ma dokładnie taki sam wydźwięk, jak jego niemiecki odpowiednik w Weisser Adler autorstwa Raoula Madera, co potwierdza też informacja o pierwotnym tytule tej opery Der polnische Reiter. 
obywateli walczących o swoje prawa). Niezaprzeczalnie opracowanie Madera jest zarówno dokumentem artystycznej recepcji muzyki Chopina, jak i postaci Tadeusza Kościuszki ${ }^{5}$ na początku XX wieku.

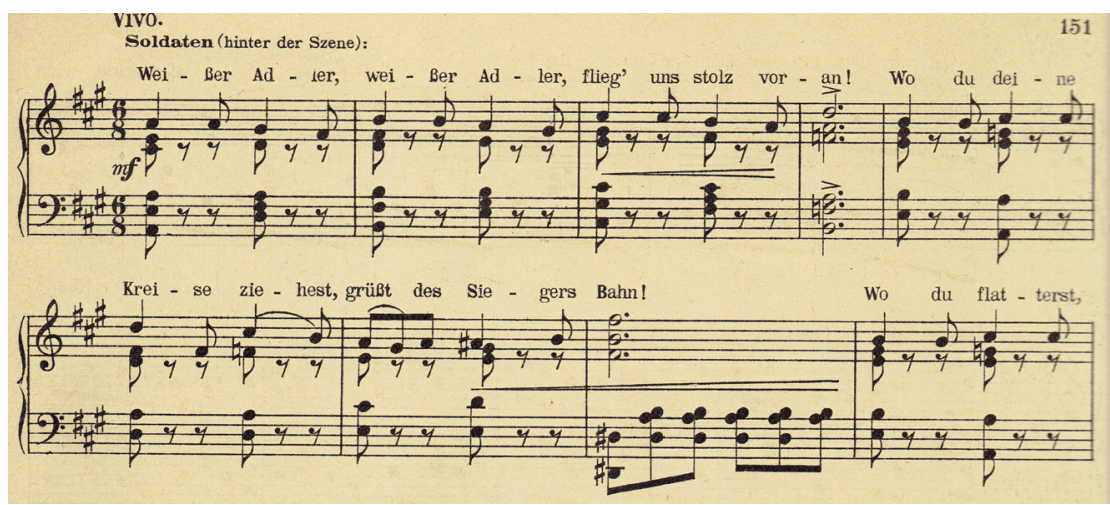

Przykł. 4. Opracowanie pieśni Fryderyka Chopina Wojak op. 74 nr Io, aria Weißer Adler w akcie III Der weisse Adler [...], opr. na fort., op. cit., s. I5I (fragment).

\section{POSTSCRIP T UM}

Każde przekształcanie muzyki Chopina wzbudzało niechęć samego kompozytora, innych twórców i krytyków muzycznych. Nie zmienia to faktu, że nieprzerwanie od I830 r. istnieje nurt prezentujący jego dzieło w najróżniejszych transkrypcjach, a jednym z jego wielu tysięcy przykładów ${ }^{\varsigma 9}$ jest opera Der weisse Adler. Pamiętamy

58 Piotr Mitzner, rozpatrując tę problematykę z okresu I803-1994, przywołuje pięć oper, w których Kościuszko jest postacią pierwszoplanową, nie uwzględnia jednak opery Der weisse Adler. W porządku chronologicznym są to: I) „Konstantego Majeranowskiego Kościuszko nad Sekwana, opera narodowa w 2 aktach, oryginalnie wierszem napisana. Z muzyką Franciszka Salezego Dutkiewicza, Kraków I82I”, zob.: P. Mitzner, op. cit., s. 25,$264 ; 2)$ „Kajetana Nowińskiego Orzet Biaty - kantata sceniczna w dwóch odsłonach, wystawiona w Lublinie w I83I roku”, zob. ibid., s. 33; 3) „Juliusa Mosena Kościuszko - opera w jednym akcie stworzona na bazie sztuki Karla von Holteia, Der alte Feldherr (Stary wódz: epizod na tle życia Tadeusza Kościuszki w jednym akcie, przeł. Adam Stodor, Lwów: Księgarnia Polska B. Połonieckiego, New York: Polish Book Importing Co, Inc. [ca 19I4] (Lwów: Zakład Drukarski «Grafia)", zob. ibid., s. 220-227, 266. Jak pisze Mitzner, prapremiera tej sztuki odbyła się I XII I825 r. w Königstädter Theater w Berlinie. Była kolejno wystawiana m.in. we Wrocławiu, Poznaniu, Bydgoszczy, Cieplicach, Hamburgu, Lipsku, Norymberdze, Frankfurcie nad Odrą, Dreźnie, Londynie. Z tej opery pochodzi pieśń Tysiąc walecznych (Die letzten Zehn vom IV Regimente bei ihrem Übergang über die preussische Grenze im Herbste des Jahres I832) z muzyką Josepha Denisa-Doche'a (ibid.). O tym fakcie wspomina także Janusz Degler w: Stanistaw Ignacy Witkiewicz. Listy do żony (1936-1939), red. Janusz Degler, Warszawa 2016, t. 4, s. 298, przyp. do listu nr 947. Piotr Mitzner obala opinię, jakoby opera Kościuszko nad Sekwanq była przeróbką Der alte Feldherr (ibid., s. 266); 4) Richarda Wagnera trzyaktowa opera Kościuszko do libretta Henryka Laubego, planowana w 1. 1832-33, jednak nie powstała. Najprawdopodobniej uwertura symfoniczna Polonia Wagnera (1832-36, prapremiera I842) jest wstępem do tej niezrealizowanej opery, zob.: ibid., s. 228; 5) Daniela Aubera opera Kościuszko (1846), zaginiona i niewystawiona, zob.: ibid., s. 229.

59 Por.: B. Literska, Dziewiętnastowieczne transkrypcje, op. cit. 
przy tym, że Chopin kochał operę i „na każdym z przystanków swej emigracyjnej wędrówki [...] regularnie odwiedzał teatry operowe, poszukując wrażeń i inspiracji”6o. Potem przekształcał zasłyszaną tam muzykę w taki sposób, aby ukazać jej autonomiczne piękno, czego efektem są jego cztery utwory ${ }^{6 \mathrm{I}}$. Odwrotny zabieg - przeniesienia autonomicznej muzyki Chopina na grunt teatru i dodania do niej narodowowyzwoleńczych treści przeprowadził Mader w Der weisse Adler. Czy ten kierunek działania znalazłby aprobatę Chopina? Czy znajduje naszą aprobatę? Ze względów polskich, patriotycznych - zdecydowanie tak. Natomiast mamy dzisiaj za mało danych, aby ocenić samo dzieło muzyczne jako utwór sceniczny. Istniejące źródła pozwalają jednak na dokonanie nowej orkiestracji partytury i stworzenie pełnej wersji opery. Byłaby to już nowa, współczesna kompozycja - kolejna transkrypcja, trzecia opera z muzyką Chopina.

RAOUL MADER'S OPERA 'DER WEISSE ADLER' AS AN EXAMPLE OF TRANSCRIPTIONS OF FRYDERYK CHOPIN'S WORKS RELATED TO POLISH NATIONAL LIBERATION THEMES

The process of transcribing Fryderyk Chopin's music by other composers and performers (instrumentalists, singers) began still in the Polish master's lifetime (in I830). Among the enormous number of Chopin arrangements, however, we only find two operas: Giacomo Orefice's Chopin (I9OI) and Raoul Mader's Der weisse Adler (1917). The former is widely known; the latter has been restored to our knowledge only now, IO2 years after its world premiere.

The present paper is an attempt at a comprehensive characterisation of the latter piece of music. The author describes the available sources, the reasons for the opera's composition, and its successive performances, as well as the libretto and the music. She focuses in particular on two aspects: I) the Polish national liberation themes, which were highly topical at the time when the opera was written (1917, directly before Poland regained independence), and 2) the various ways in which Chopin's music was transcribed specifically for the needs of an operatic spectacle.

The former topic is discussed in the form of a detailed analysis of the libretto, as compared to historical facts. Based on this analysis, the author concludes that the opera emphasises the national liberation themes. It underlines Tadeusz Kościuszko's achievements during the

60 Alina Borkowska-Rychlewska, ,Poza murami teatralnego gmachu - o operze in abstracto (na podstawie korespondencji Fryderyka Chopina i Dzienników Eugène’a Delacroix", w: Opera wobec historii, op. cit., s. 57-72; A. Rembowska, „Chopin i opera”, Teatr 50 (1995) nr Io, s. 9-Io.

6I Wariacje B-dur op. 2 na temat Là ci darem la mano z opery Don Giovanni Mozarta na fortepian i orkiestrę; Wariacje B-dur op. I2 na temat ronda Je vends des Scapulaires z opery Ludovic Hérolda i Halévy'ego; Wariacje E-dur (bez op.) na temat Non più mesta z opery Kopciuszek Rossiniego na flet i fortepian; Grand Duo Concertant E-dur na temat z opery Robert Diabet Meyerbeera na fortepian i wiolonczelę. 
Kościuszko Uprising of I794, and places the national symbol - the White Eagle - in the very title. Such themes are also present in the graphics found on the score cover and in the text of the opera's leitmotiv hymn.

The latter question - that of the ways in which Chopin's music was arranged in the opera - is examined using Maciej Gołąb’s (2003) classification of Chopin transcriptions. The author defines the types of transcriptions found in Mader's piece on the basis of detailed comparison of the opera numbers with Chopin's originals.

In the conclusion of the paper, the author outlines the possibilities for further research, and emphasises that Mader's opera is a document of Chopin music reception in the artistic circles, and of the figure of Tadeusz Kościuszko in early 2oth-century Vienna.

Translated by Tomasz Zymer

Słowa kluczowe / keywords: Chopin w operze / Chopin in opera, transkrypcje muzyczne / musical transcriptions, recepcja Chopina / Chopin's reception, Tadeusz Kościuszko w operze / Tadeusz Kościuszko in opera.

Dr hab. Barbara Literska, profesor Uniwersytetu Zielonogórskiego, teoretyk muzyki, muzykolog. Jej zainteresowania badawcze dotyczą przede wszystkim recepcji muzyki Fryderyka Chopina oraz dwudziestowiecznej polskiej twórczości kompozytorskiej. Jest autorką dwóch monografii: Tadeusz Baird. Kompozytor, dzieto, recepcja (2012) oraz Dziewiętnastowieczne transkrypcje utworów Fryderyka Chopina: aspekty historyczne, teoretyczne i estetyczne (2004), licznych artykułów, współredaktorką prac zbiorowych. Jest członkiem Polskiego Towarzystwa Analizy Muzycznej oraz Lubuskiego Towarzystwa Naukowego, recenzentem czasopisma Interdisciplinary Studies in Musicology, członkiem rady redakcyjnej Rocznika Chopinowskiego oraz rosyjskiego czasopisma Vestnik Kemerovskogo gosudarstvennogo univeriteta kul'tury i iskusstva.

\title{
Drugi tom serii „Muzyka polska za granicą”
}

\author{
Między Warszawą a Paryżem (1918-1939) \\ red. Beata Bolestawska-Lewandowska i Jolanta Gusy-Pasiak
}

iswydawnictwo@ispan.pl 